\title{
Do growth-promoting factors induce income inequality in a transitioning large developing economy? An empirical evidence from Indian states
}

\author{
Amit Nandan ${ }^{1} \cdot$ Hrushikesh Mallick $^{1}$
}

Received: 11 January 2021 / Accepted: 25 June 2021 / Published online: 1 July 2021

(c) The Author(s), under exclusive licence to Springer Science+Business Media, LLC, part of Springer Nature 2021

\begin{abstract}
We examine the role of the enforcement of property rights, human capital formation, and the efficiency of various components of state governments' developmental expenditure on states' economic growth and interstate income inequality. Together with private sector investment in rural areas, property rights enforcement, human capital, government expenditures on economic services, and health and education are found to have positive effects on states' growth. We also observe that the interstate difference in the provisioning of government economic services is the leading factor in contributing to interstate income divergence in India. These findings can serve as vital technical inputs for formulating economic policies to achieve faster economic growth and mitigate regional income inequality in transitioning developing economies like India and hold greater relevance for other developing economies on their way to experiencing similar social and economic transitions.
\end{abstract}

Keywords Public expenditure · Human capital · Private property rights · Growth · Income inequality

JEL Classification $\mathrm{H} 4 \cdot \mathrm{I} 152 \cdot \mathrm{I} 25 \cdot \mathrm{K} 11 \cdot 04 \cdot 015$

Hrushikesh Mallick

hrushi@cds.ac.in; hrushi_isec@yahoo.co.in

Amit Nandan

amit18phd@cds.ac.in; amitnandan15@gmail.com

1 Centre for Development Studies (CDS), Prasanth Nagar, Medical College PO,

Ulloor, Trivandrum 695011, India 


\section{Introduction}

Tracing the historical roots of the Indian economy, which currently features in the league of lower-middle-income developing economies, a dramatic transition is evident, from over three decades of slow growth (famously called as the "Hindu rate of growth") after independence till its emergence as one of the fastest-growing economies post the 1990s. ${ }^{1}$ The latter phase is mainly associated with the pursuit of liberalization measures in 1991, which were implemented against the backdrop of an external economic crisis in the early 1990s. The major macroeconomic policies undertaken in that period had far-reaching impact in terms of safeguarding the economy from various turbulences including the South-East Asian Financial Crisis of 1997-1998 and the Global Financial Crisis of 2007-2010 - and helping it chart out its course toward one of the fastest-growing economies in the world. However, in recent years, the economy has been growing at a slower pace and is yet to join the league of upper-middle per capita income countries such as China, Malaysia, Thailand, Indonesia, Brazil, Turkey, and South Africa. Furthermore, given its recent slow pace of growth that is also inflicted with the onset of the global COVID-19 pandemic since the beginning of 2020 has complicated matters. The recent slowdown of the Indian economy can be attributed both to the global economic slowdown and the slump in domestic industrial investment demand, a key driving force behind the success of major industrial economies today. Notwithstanding India's remarkable success in ameliorating the high poverty ratio and achieving robust economic growth performance during the post-liberalization period, the rising income inequality has posed a more serious and intense challenge for macroeconomic policymaking since 2000. India has emerged as a highly unequal society compared with its Asian neighbors such as China. The inequality has persisted because of the substantial increase in the unemployment rates of both educated and uneducated labor forces, slow upward social mobility, lack of work opportunities and freedom of choice for women to participate in various economic activities and decision-making process. Besides, the lack of social security and government welfare programs for the elderly and women, all indicate toward the structural rigidities and institutional weaknesses in the system. In this context, this study makes a valuable contribution to the literature by examining the effects of fiscal policies and quality of governance on the economic growth of Indian states in the post-liberalization period. The findings offer significant policy insights across various social and economic dimensions for promoting social welfare. Additionally, in line with the endogenous growth framework this study endogenizes the effects of institutional quality and human capital formation as key factors, which can play critical role in driving the higher economic growth of Indian states. We further examine whether any of the growth-promoting

\footnotetext{
1 The "Hindu rate of growth" in the Indian literature refers to the annual growth rate of the Indian economy prior to the economic reforms of 1991 that stagnated at around 3.5\% from the 1950 s to the 1980 s, while per capita income growth averaged at around 1.3\%. This term was coined by a prominent Indian economist Raj Krishna in 1978, who attributed this slow growth to India's socialist policy outcomes.
} 
factors can induce higher inequality in income distribution across the sub-federations in India (Chancel and Piketty, 2019; Hai-Anh and Lanjouw, 2018). ${ }^{2}$

For an understanding of factors leading to economic growth in various regions, the seminal contribution of Solow(1956), which constitutes the very foundation of the development of the neoclassical growth model, is at the forefront of public policy discussions. Solow (1956)'s analysis demonstrated that the long-run growth of an economy depends on exogenous factors such as technological progress and population growth. The growing literature in the late 1980s and early 1990s countered the central tenets of Solow and supported the intrinsic ideas embedded in endogenous growth theory. The critique further advocated that growth is an endogenous outcome of an economic system(Romer 1994). The long-run growth of an economy is driven by the actions of forward-moving and profit-oriented agents who invest in the creation and accumulation of knowledge, which in turn generates positive spillovers or externalities for other economic agents(Romer 1986).

Further, Lucas (1988), while highlighting the importance of physical capital in achieving higher growth, simultaneously emphasized the contribution of human capital in economic growth. He defined human capital as, "the ways an individual devotes his time in comparison to other activities in the current period, which affects her/his productivity in the future periods". Thus, individuals who devote their time to academia and learning various skills, rather than joining the labor force in the current period, may benefit society in the future through higher productivity. This newly formed human capital has positive externalities that lead to the productivity growth of other individuals, and therefore, to long-run economic growth. Barro (1990) adopted an endogenous growth framework while assessing the role of public expenditure policy in his growth model, concluding that there were components of public expenditure that contribute to the long-run growth of an economy by augmenting private sector investment, known as productive public expenditure.

Factors such as human capital formation and knowledge creation in the form of research and innovation are widely acknowledged as essential components of a knowledge economy with international and internal migration dynamics that lead to external resources in the form of remittances and greater investment productivity; these help achieve greater competitiveness and comprise productive public expenditures that generate long-run economic growth. ${ }^{3}$ With a view to refine the existing

\footnotetext{
2 According to the CIA World Fact Book (2011), the richest $1 \%$ of Indians owned $58.4 \%$ of wealth, while the richest $10 \%$ owned $80.7 \%$. This annual trend has been on the rise, implying that the rich are getting richer at a faster rate than the poor improving their income and wealth. Furthermore, while poverty has been reduced, households that have escaped poverty have a high risk of relapsing. The IMF's (2016) regional economic outlook for Asia and the Pacific reported that India's Gini coefficient rose to 0.51 in 2013 from 0.45 in 1990 . In 2017, the top $10 \%$ of Indian population held $77 \%$ of the total national wealth, and $73 \%$ of the wealth generated in 2017 went to the richest $1 \%$ - the 67 million Indians who comprise the poorest half of population saw only a $1 \%$ increase in their wealth.

3 The Chinese economy can be treated as a real world example that is in the advanced stage of a knwoledgable economy in the developing world. Knowledge and information are the key drivers of productivity both in public and private sectors that characterize the economy. It has an institutional structure that provides incentives for entrepreneurship and greater dependence on knowledge. It induces innovation with the availability of its skilled labour forces and the use of ICT.
} 
ideas and advance new theories, some later economists additionally accredited the significant role of institutions as a determinant of cross-country long-run growth. They explored how institutions affect the decisions of economic agents, and whether differences in economic growth can be explained by differences in institutional quality across economies (North 1986).

Institutional economists should investigate the implications of rules or norms on the enforcement of property rights and contracts, and their analyses should be based on political process models (North, 1986). Acemoglu et al. (2005) believed that political institutions and resource distribution affect economic outcomes through economic institutions. Political institutions include the form of government, constraints on political leaders, other power-holding elite groups and the demarcation of power among different organs of the government, whereas economic institutions mainly include property rights and contract enforcement. Political institutions shape political incentives and separation of powers, whereas economic institutions and policy enforcement affect economic outcomes through incentive mechanisms and by improving the consistency in decision-making processes of various economic actors (North 1991; Acemoglu et al. 2005). ${ }^{4}$ Besely and Ghatak (2010) emphasized four principal channels whereby secure property right produces better economic outcomes and thereby promotes the efficiency in a market-based economy. ${ }^{5}$

Besides property rights, contract enforcement is also an important part of the economic institution that supports a flourishing market economy. Market-based production requires a developed capital market to finance fixed investment in equipment and tools, trained labor, a developed transportation system, and a market for inputs and outputs. A robust contract enforcement system seamlessly coordinates and decreases the costs associated with economic transactions. The decrease in costs associated with transactions helps economic agents realize the benefits of mutual cooperation, despite their physical distance. A specific region may have an informal contract enforcement mechanism that facilitates transactions among economic agents; however, the costs due to informality can exceed their benefits. Banerjee (2001) documented the informal money-lending system in India, wherein the contracts between borrowers and lenders are enforced through an informal system. Because of high associated transaction costs, the rates of interest charged on loans are exorbitant and that act as a deterrent for the poor availing the loans. Even they receive the amount in the current period, it imposes substantial future obligations on them.

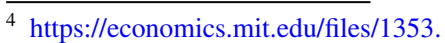

${ }^{5}$ First, it helps economic actors realize the fruits of investment. Second, secure property rights release extra resources for productive activities that an individual would otherwise allocate to defend the property in the absence of security, or if it checks the rent-seeking behaviour of individuals. Third, it facilitates the realization of gains from trade and lubricates other transactions. Last, secure property rights help an individual to use their assets as collateral in financial markets to secure loans for other productive activities.
} 
Given that there exist extensive contributions to the growth literature on many dimensions, this study examines the effects of enforcement of property rights as an important economic institution, along with incorporating four sub-components of developmental public expenditure, private investment and the role of human capital on the economic growth of Indian states in a dynamic panel framework from 1991 to $2017 .{ }^{6}$ Furthermore, this study goes a step further by investigating a muchdebated issue based on the pioneering Kuznets curve hypothesis, which suggests that the relationship between per capita income and inequality follows an invertedU-shaped curve. Many researchers such as Kar and Sakthivel (2007), Nayyar (2008), and Kumar and Subramanian (2012) have observed that income inequality has been widening among the Indian states with the adoption of market-based reforms since the early 1990s. Therefore, it becomes pertinent to analyze the factors affecting income inequality in the present context, because persistent growth in income disparities can lead to political instability, thereby endangering the liberal democratic ethos of the country. Ahluwalia (2000) argued that the continued growth of interstate income inequality among Indian states can be one of the main reasons contributing to the growth of future political uncertainty and instability in India. Mounk (2018) noted that the growth of income inequality in a country is one of the main factors leading to political instability and threatening liberal democracy. This study is the first to examine the issue of growth-promoting income inequality-inducing factors in a dynamic multivariate regression framework for a developing economy or even for a region. Given the worsening interstate income inequality in India, we examine whether growth-impacting variables based on our growth model estimation (measured in per capita gross domestic product (GDP) can explain interstate income disparity during the same period. Thus, this study makes a twofold contributions. First, it examines the factors affecting per capita income growth. Second, it explores whether our model's growth-influencing factors also explain the interstate income differences across major Indian states.

To empirically examine these two objectives, we use pooled mean group (PMG) econometric method for estimation of a standard growth model along the line as envisaged by the endogenous growth theory which is specified later and then we use an autoregressive distributed lag (ARDL) time-series model for the estimation of income inequality model as a suitable econometric estimation strategy. The next section discusses the existing relevant empirical literature on those two dimensions with a special emphasis on India, to glean broad insights about the key factors influencing economic growth and inequality over time. This would also reflect on the factors which so far have been recognized to be influencing India's economic growth and income inequality.

\footnotetext{
6 This study considers 16 non-special category states which covers about $85 \%$ of total geographical areas of India. It excludes special category states on account of their features such as (1) located in hilly and difficult terrains, (2) low population density and sizable share of tribal population (3) strategic locations bordering the neighboring countries, (4) economic and infrastructural backwardness and (5) non-viable nature of state finances. Due to these reasons, Nandan and Mallick(2020) have selected these states in their study.
} 


\section{Empirical literature}

In a pioneering work, Barro (1991) observed that the per capita growth rate of countries is positively associated with human capital and political stability, while it is inversely related to the ratio of government consumption expenditure to the GDP for 98 countries during 1960-1985. Benhabib and Spiegel (1994), in a cross-country analysis, found that although human capital did not explain per capita income growth, it explained the total factor productivity growth.

Further, Easterly and Rebelo (1993) examined the effects of fiscal policy on the incomes of 100 countries during 1970-1988. He observed that transportation and communication expenditures have a robust positive correlation with income growth. For a panel of 22 Organization for Economic Co-operation and Development (OECD) countries during 1970-1995, Kneller et al. (1999) established that countries' productive government expenditures enhance their growth rates. Gupta et al. (2005) similarly concluded that public outlays on capital heads lead to faster output expansion for 39 low-income countries in the 1990s. Conversely, Devarajan et al. (1996) and Ghosh et al. (2008) observed that an increase in current public expenditure is significantly associated with income growth.

Acemoglu et al. (2001), in their seminal work, examined the role of institutions on the economic development patterns of countries that were subjugated by European imperialism. They used the mortality statistics of Europeans in these conquered countries as a proxy for the quality of institutions and found that Europeans established only extractive institutions in the countries where they faced high mortality rates. Furthermore, they established their own institutions (such as property rights and separation of powers between different organs of government) in places where they found conducive environments for settlement. They argued that differences in the economic development patterns across the countries today can be ascribed, to a major extent, to differences in institutional quality. In exploring the effects of institutions, geography, and trade on the per capita income of several countries, Rodrik et al. (2004) in their insightful work observed that it is the quality of institutions that trumps over the other factors in explaining inter-country per capita income differentials.

Although wider literature has analyzed various factors influencing economic growth for a cross section of countries, the above survey indicates that differentials in income levels are mostly explained by the countries' quality of institutions, human capital formation, and components of developmental public expenditures, which have not been comprehensively analyzed for a large number of developing economies including India.

\subsection{Literature on India}

Examining 20 Indian states, Cashin and Sahay (1996) observed that notwithstanding the widening per capita income gap, grants from the central government to poorer states helped reduce interstate income differentials. Rao et al. (1999) and Ahluwalia 
(2000) concluded that regional disparities in private investment and literacy were the main factors contributing to rising regional income disparity between 1986 and 1997. Sachs et al. (2002) found that the degree of urbanization across states explained the regional income differentials. Besley and Burgess (2004) investigated the effects of labor market regulation on manufacturing growth across states. They observed that the states that had implemented regulations favoring laborers had experienced lower output, employment, and productivity growth in the formal manufacturing units. Amin and Matto (2008) observed a positive relationship between per capita service sector outputs and the availability of skilled labor force across states. Kar and Sakthivel (2007) attributed the growing interstate income differential to the adoption of the market-led policy of 1991. Aghion et al. (2008) noted that after the adoption of India's de-licensing policy, industries preferred to locate in states that had implemented pro-employer labor regulations, and this was reflected in the industrial output differentials across states. Aiyer and Mody (2011) investigated the relationship between economic growth and demographic features across states. They found that a positive relationship existed between income growth rate and the growth rate of young population or the level of the working-age population. They concluded that the presence of a younger population was one of the crucial factors which helped India to achieve high economic growth.

Banerjee et al. (2002) examined the effects of restricted (limited) property rights given to sharecroppers in West Bengal under the West Bengal Land Reforms Act of 1977 on the state's agricultural productivity. They found that the transfer of limited property rights from landlords to sharecroppers enhanced agricultural productivity growth on account of two factors: (1) strengthening of bargaining power, and (2) security of tenure. Banerjee and Iyer (2005) explored the implications of the different forms of land revenue settlements imposed by the British in India on economic indicators like agriculture investment, productivity, and investment in education and health. They found that areas that were under the permanent landlord system (zamindari system) had a low investment in agriculture and low public expenditure on health and education compared with the areas that were under the raiyatwari (individual cultivator-based) and mahalwari (village-based) systems even post-independence.

\section{Underlying theoretical framework}

Our analysis builds on Barro (1990) to establish the relationship between government expenditure allocations and economic growth. Assuming that there are infinitely lived households that pursue utility maximization, the utility function for a representative household is as follows:

$U=\int_{0}^{\infty} u(c) e^{-\rho t} d t ;(1)$, where c denotes consumption per person, and $\rho>0$ is the constant rate of time preference. The utility function is described by.

$u(c)=\frac{c^{1-\sigma}-1}{1-\sigma} ;(2)$ and the constant elasticity, $\sigma>0$ is assumed. Each household is also a producer of certain goods, whose production function is given by 
$y=f(x)$; (3) where $\mathrm{y}$ and $\mathrm{x}$ denote output per worker and capital per worker. Each person works for fixed hours; hence, there is no labor-leisure choice.

The rate of growth of consumption after maximization of utility function (1) can be given by:

$$
\frac{\dot{c}}{c}=\frac{1}{\sigma} \cdot\left(f^{\prime}-\sigma\right) ;(4)^{\prime} \text { where } f^{\prime} \text { refers to the marginal product of capital. Now, }
$$
assuming the production function to be $y=A k ;(5)$, the per capita growth rate can be represented as $\gamma=\frac{\dot{c}}{c}=\frac{1}{\sigma} \cdot\left(\begin{array}{c}\prime \\ -\sigma\end{array}\right)$. To ensure that there exists a steady-state growth rate, it is assumed that $A>\rho>A(1-\sigma)$.

Now, the government sector is introduced, which affects both production and consumption, not only at the household levels (micro-level), but also at the aggregate level of the economy. This is because the government provides public services $g$, free of congestion effects, and these act as inputs for private production.

Thus, the new production function can take the following form $y=\Phi(k, g)=k \cdot \phi\left(\frac{g}{k}\right) ;(6)$ with $\emptyset^{\prime}>0$ and $\emptyset^{\prime \prime}<0$. The final Cobb-Douglas form of the production function can be written as:

$\left.\frac{y}{k}=\Phi\left(\frac{g}{k}\right)=A \cdot\left(\frac{g}{k}\right)^{\alpha}, 0<\alpha<1\right)(7)$ which constitutes the basic model based on which the subsequent empirical analysis is designed. ${ }^{7}$

Similar to Barro (1990), by introducing the mechanism of government allocations, the present analysis orients the focus on government services in the production function. However, rather than focusing on per unit capital availability of output on the one hand and aggregate government services provisioning on the other, we consider per capita income in our empirical analysis and then relate it to the various categories of government services relative to the gross state domestic product (GSDP). We, therefore, examine the effects of the various components of government expenditures on per capita income of Indian states. All other variables in our empirical model can be treated as control variables or input variables.

Given the above context, the study contributes to the literature by examining whether the enforcement of property rights, as an important economic institution, is crucial to states' economic growth. Additionally, the role of various components of developmental public expenditure, such as on health and education, economic services, welfare, urban development and housing, together with private investment and human capital formation, are incorporated in a multivariate dynamic framework.

\footnotetext{
7 Assuming that the government expenditure is financed by a flat tax rate; $g=T=\tau y=\tau \cdot k \cdot \emptyset\left(\frac{g}{k}\right) ;(8)$ and after doing some simple algebraic manipulations in few steps, one will arrive at the steady-state growth rate of the economy, which can be shown as (all the quantities grow at the same rate); $\gamma=\frac{\dot{c}}{c}=\frac{1}{\sigma}\left[(1-\tau) \cdot \emptyset\left(\frac{g}{k}\right) \cdot(1-\eta)-\rho\right](9)$.
} 


\section{Modal specification and variable choice}

We specify an extended version of Barro (1990)'s basic growth model as in Eq. (1), expressed in terms of real per capita incomes, which is given as follows:

Real Percapita Income $_{i t}=\alpha+\beta_{1}$ Property Right Enforcement $_{i t}+$
$\beta_{2}$ Private Corporate Investment $_{i t}+\beta_{3}$ Pr ivate Investment In Rural Areas It $_{i t}+$
$\beta_{4}$ Human Capital $_{i t}+\beta_{5}$ Public Expenditure on Economic Services $_{i t}+$
$\beta_{6}$ Public Expenditure on Health\&Education $_{i t}+$
$\beta_{7}$ Public Expenditure on Hou $\sin g$ \&Urban Dvelopment $_{i t}+$
$\beta_{8}$ Public Expenditure on Welfare
$i t$

where $u_{i}$ captures unobservable effects and $v_{i t}$ represents the standard error term.

Based on institutional economics and endogenous growth theories, we can expect a positive relationship between the enforcement of property rights and economic growth. Similarly, we can also expect a positive relationship between human capital formation and economic growth. However, it is difficult to predict the kinds of relationships that exist between the different components of public development expenditure and per capita income for a developing economy like India. After specifying the growth model, a likely specification for the income inequality model (2) follows:

$$
\begin{aligned}
& \text { InterState Income Inequality }_{i} \\
& \begin{aligned}
= & \alpha \beta_{1} \text { Inter State Inquality in Property Right Enforcement }_{i} \\
& +\beta_{2} \text { Interstate Inequality of Human Capital }_{i} \\
& +\beta_{3} \text { Interstate Inequality of Private Investment }_{i} \\
& +\beta_{4} \text { Interstate Disparity in Provision of Pubic Services }_{i}+\varepsilon_{i}
\end{aligned}
\end{aligned}
$$

where $\varepsilon_{i}$ represents the standard error term, and the other variables incorporated are self-explanatory. The final income inequality is specified after the estimation of the income growth model of Eq. (1).

\subsection{Data sources and variable description}

The statistics related to real per capita income, public expenditures, human capital formation, population and GSDPs are all drawn from the Economic and Political Weekly Research Foundation (EPWRF) and the Reserve Bank of India (RBI). ${ }^{8}$ As

\footnotetext{
8 The two broad developmental expenditure heads for states, revenue and capital, are subdivided into four components. Economic services expenditure comprises combined economic services expenditure for revenue and capital accounts. However, social service expenditures (from both revenue and capital accounts) are further decomposed into three components: (i) health \& education, (ii) welfare, and (iii) housing \& urban development. The data for newly created states (Jharkhand, Chhattisgarh, Uttarakhand, and Telangana) are combined with their origin states.
} 
state-wise private investment statistics are not reported by any authentic or governmental statistical agency sources, we, therefore, use a suitable proxy derived from the CapEx database of the Centre for Monitoring of Indian Economy (CMIE), for which the data are available. It provides data on projects completed, projects outstanding and projects abandoned by the private sector. The CapEx captures the costs of private investment projects exceeding 10 million Indian Rupees (Bahal et al. 2018). This study considers the information on projects completed because such projects crucially affect economic growth and are labeled private corporate investment. The RBI also provides annual data on state-wise agriculture credit provided by Indian Scheduled Commercial Banks(SCBs) and Regional Rural Banks(RRBs). This captures the private investment in rural areas, labeled as private investment in rural areas. The government also allocates a significant portion of funds in rural areas for the development of irrigation, flood controls, animal husbandry, and rural roads. Agricultural credit is likely to capture the response of private investment to increased public development expenditures. Two types of private investment variables are considered here to understand their role and nature. Private corporate investment captures the formal sector investment (including foreign firms), whereas private investment in rural areas (proxied by agricultural credits extended by SCBs and RRBs) captures the informal investment. ${ }^{9}$

The National Crime Records Bureau (NCRB) of India provides state-wise statistics on the values of the property stolen and recovered by the police. We consider the percentage recovery of stolen property as a measure of protection of property rights or as an indicator of the quality of economic institutions. ${ }^{10}$ All Indian citizens (and non-citizen residents) have property rights, but the effectiveness of government agencies like the police forces in defending the property rights of individuals is what crucially influences the faith of the people in the country's institutions. The Federation of Indian Chambers of Commerce and Industry (FICCI) in its various reports has mentioned, "One of the main factors for the rapid growth of private security sector in India is the lack of ability of government agencies to provide adequate security to private property." ${ }^{11}$ We also include the gross enrollment of students in higher

\footnotetext{
${ }^{9}$ Burgess and Pande (2005) examined the effects of the state-sponsored banking expansion program on poverty in India. The motive of this state-sponsored program was to examine the effects of bank expansion in rural unlocked areas, and it was successful in expanding the banking network in the financially less-developed regions of a state. They found that the state-sponsored bank expansion policy (in terms of extension of rural bank credits) helped in the reduction of rural poverty, and this reduction was linked to an increase in savings and credit provisioning. Moreover, this helped rural households accumulate more capital and obtain loans for long-term productive investments.

${ }^{10}$ Iyer et al. (2012) have also used NCRB data source to get state-wise information on crimes against women.

${ }^{11}$ Indian private security industry preparing for the next leap (Source: Federation of Chambers of Commerce \& Industry). Private security industry job creation and development (Source: Federation of Chambers of Commerce \& Industry). This phenomenon has a detrimental effect on economic growth. The literature suggests that if the government cannot enforce property rights, then individuals will engage in rent-seeking behaviors or divert productive resources to protect their personal property. Large corporate houses successfully bear the extra costs of defending their enterprises or properties by deploying private security guards or other advanced modern security technologies, but small and marginal entrepreneurs are unable to do so. The extra amount spent on providing security can be used in other productive activities, and this adversely affects small producers or economic agents.
} 
education (including a bachelor's degree and above) expressed as a percentage of the total population between 20 and 29 years of age as a variable to capture the effects of human capital formation. This is drawn from the All India Survey on Higher Education (AISHE) that provides statistics on the number of students enrolled in higher education in all categories of institutions (private and government). Researchers have widely used primary, secondary or even literacy rates to capture human capital formation (Benhabib and Spiegel 1994; Levine and Renelt 1992; Loayza and Ranciere 2005; Nagaraj et al. 2000; Rao et al. 1999). These data are based on decadal census information. Therefore, extrapolating/interpolating the data posed a problem on account of the lack of their variability. It is well established that there are higher dropout rates in India at the primary, secondary, and senior secondary stages. Therefore, to address this problem, we have used the AISHE statistics, which have the following benefits. First, it states with certainty the specific percentage of students that completed their senior secondary education level-the dropout rate is not as high as for senior secondary school education. ${ }^{12}$ Second, it provides year-wise and statewise data that shows a more real picture of the situation prevailing in Indian states.

All the four components of developmental public expenditure-economic services, health and education, housing and urban development, welfare-and private corporate investment and private investment in rural areas are expressed as a percentage to the GSDPs of the respective states. Table 1 provides the descriptive statistics of the variables. The standard deviations of all public expenditure variables are much lower than the other variables mentioned. Table 8 in Appendix provides the average values of some of the variables, such as property rights enforcement, human capital formation, and credit given by SCBs and RRBs. We find that the economically richer Indian states, such as Gujarat, Maharashtra, Punjab, Haryana, Goa, Tamil Nadu, Karnataka, Andhra Pradesh, and Kerala, mostly outperform in human capital formation compared with the economically poor states. In enforcing property rights, Andhra Pradesh, Haryana, Punjab, Karnataka, Punjab, Tamil Nadu, Rajasthan, Madhya Pradesh, and Uttar Pradesh perform well (compared with a threshold value of 0.35 ). The lower figures for some of the economically developed states reflect the growth of the private security sector or that the police forces focus more on cases related to national security, rather than civil issues (FICCI's report on Private Security Industry). ${ }^{13}$ The agricultural credit follows the patterns of

\footnotetext{
12 The AISHE provides data of students enrolled in central universities, central open universities, institutes of national importance, state public universities, institutes under state legislature act, state open universities, state private universities, deemed universities, etc. Except for a few cases, we are aware of the level of entrance tests through which students get admission into these institutions.

13 Private security industry job creation and development (Source: Federation of Chambers of Commerce \& Industry). These states also share boundaries with the Arabian Sea, and the perceived threat of terrorist attacks is always high. It is also possible that in these states, police forces may have to deal more with other economic offences such as criminal breach of trust, cheating, forgery, and counterfeiting. Banerjee and Iyer (2005) also pointed out that in economically poor regions, cases like kidnapping and robbery are more prevalent. The main limitation of our variable (capturing the quality of economic institutions through property right) is that it is unable to capture other economic offences such as criminal breach of trust, cheating, forgery, and counterfeiting. We are unable to account economic offences because the NCRB has recently started publishing such data and it is not available for prior years. However, the property right is one of the important dimensions of economic institution.
} 
the share of agriculture and allied activities in states' GSDPs. The correlation coefficient between the average credit given by SCBs and RRBs and the average share of agriculture and allied activities in the states' GSDPs is 0.58 .

\section{Econometric estimation strategy}

We consider 16 major states of India spanning 27 years (from 1991 to 2017) for this analysis. Because the number of years (observations) is more than the crosssectional units in the study, these panel data are therefore characterized as macropanel data. Two key issues need special attention while estimating the coefficients of any macro-panel data set: (i) those who do not believe in the homogeneity argument of regression parameters, and (ii) those who are more concerned about time-series properties like cointegration, spurious regressions and non-stationarity (Baltagi, 2005 page 237 ).

Econometricians who do not believe in the homogeneity argument are more concerned with dynamic relationships (lagged dependent variable as a regressor). However, ignoring the heterogeneity of slope parameters in the dynamic regression can give rise to inconsistent and misleading parameter estimates if the estimates are derived through pooled and aggregate estimators (Pesaran and Smith 1995). Alvarez and Arellano (2003) mentioned that within groups (WG), generalized method of moments(GMM), and limited information maximum likelihood (LIML) estimators yield negative asymptotic biases of orders, $1 / N$, and $1 /(2 N-T)$, respectively, when $T / N$ takes a positive constant value. Another important characteristic of macro-panel data is the presence of cross-sectional dependence. Cross-sectional dependence may arise due to common global shocks, spatial dependence, common institutions, etc. (Phillips and Moon 1999). The presence of cross-sectional dependence in dynamic panel estimators may give rise to severe biases in the parameter estimates, resulting in a loss of estimation efficiency (De Hoyas and Sarafidis 2006). The presence of cross-sectional dependence in the macro-panel data set is more likely especially when one is dealing with sub-federal units states that are parts of a nation. This is because there is free movement of people, goods, and other factors of production throughout a country. ${ }^{14}$ Therefore, it is necessary to control for such cross-sectional dependence while estimating a panel model.

\subsection{Cross-sectional dependence and panel unit root tests}

Several existing tests verify the cross-sectional dependence in panel data series. The Lagrange multiplier (Breusch and Pagan 1980) is based on the squared pair-wise Pearson's correlation coefficients and is applicable if $\mathrm{T}$ is much larger than N. Pesaran (2004) also proposed a new test, the Pesaran CD test, which is

\footnotetext{
${ }^{14}$ Free movement is restricted in specific regions that are under the Sixth Schedule of the Indian Constitution. It deals with the tribal areas of India's northeastern states. However, these states have not been considered in this study. https://pib.gov.in/newsite/erelcontent.aspx?relid=92687.
} 
Table 1 Descriptive statistics

\begin{tabular}{llrr}
\hline Variables & Observations & Mean & SD \\
\hline Real per capita incomes (in thousand) & 432 & 74.47 & 53.88 \\
Property right enforcement & 432 & 32.46 & 18.90 \\
Human capital formation & 432 & 6.76 & 3.83 \\
Private investment in rural areas & 432 & 4.85 & 2.98 \\
Private corporate investment & 432 & 4.08 & 6.99 \\
Public expenditure on economic services & 432 & 4.35 & 1.97 \\
Public expenditure on health and education & 432 & 3.76 & 1.12 \\
Public expenditure on housing and urban development & 432 & .35 & .26 \\
Public expenditures on welfare & 432 & .78 & .46 \\
\hline
\end{tabular}

based on an average value of pair-wise correlation coefficients of ordinary least squares (OLS) residuals from the individual panel regressions. This test is applicable where both $\mathrm{N}$ and $\mathrm{T}$ are fixed and also whenever there are single or multiple breaks in the coefficients of slopes/error variance. Pesaran and Yamagata (2008) developed a new bias-corrected version of the Lagrange multiplier test that is consistent even when the Pesaran CD test is not.

There exist six-panel unit root tests-Levin-Lin-Chu (LLC), Harris-Tzavalis (HT), Breitung test (BT), Im-Pesaran-Shin test (IPS), Fisher-type test, and Hadri LM test-each different from the other. The IPS and Fisher-type tests are applicable when one has to deal with unbalanced panel data (STATA Manual, 2013). Hadri, LLC and IM have a restrictive assumption: the panel data should satisfy the cross-sectional independence property (Pesaran 2007). However, the Breitung method is robust even for the presence of cross-sectional dependence in data (Breitung and Das 2005). Pesaran (2007) proposed a new test to handle the presence of cross-sectional dependence in data. In this method, the standard augmented Dickey-Fuller (ADF) regressions are augmented with the lagged levels of cross-section averages, and the first difference of individual series. This method is popularly known as cross-sectionally augmented ADF or CADF.

Each test also varies with respect to the inclusion of autoregressive parameters. The LLC, HT, and BT assume that all the panels have the same autoregressive parameters, whereas the IPS and Fisher-type tests are based on panelspecific autoregressive parameters. The next assumption relates to the dimension of the data, that is, the number of cross-sectional units $\mathrm{N}$ and time periods $\mathrm{T}$, which either tend to infinity or some fixed number. The assumption regarding the dimension of panel data is provided in Table 4 of Appendix.

The panel data set used in this study is a balanced panel with $\mathrm{N}=16$ and $\mathrm{T}=27$. Hence, based on the asymptotic property provided in Table 4 of Appendix, the LLC test is chosen to check the presence of a unit root. However, the limitation of the LLC is that it does not account for the presence of cross-sectional dependence. Therefore, Levin et al. (2002) suggested using this test only after the cross-sectional de-meaning of data. If cross-sectional dependence exists, the series must be 
de-meaned before using the LLC unit root test. A BT panel unit root test can also be used if cross-sectional dependence exists in data; however, the asymptotic requirements of this test are $(N, T \rightarrow \infty)$.

\subsection{Cross-sectional dependence and panel unit root results}

Table 5 in Appendix shows the results of the cross-sectional dependence test. The results, in line with a priori expectations, show the presence of cross-section dependence across the series. Similarly, the panel unit test results (Table 6 of Appendix) show combinations of $I(0)$ and $I(1)$ variables. Hence, the present econometric estimation method is based on specific data features.

\subsection{Application of econometric models}

Pesaran et al. (1999) proposed the pooled mean group (PMG) estimation in a panel data context, which is based on the autoregressive distributed lag (ARDL) approach. This estimator allows the intercept, short-run coefficients, and error variances to vary across the cross-sectional units but imposes the same long-run coefficients across units. The parameter estimates derived with the use of panel data are found to be robust even if regressors are of mixed order of integration (both stationary and non-stationary), but the dependent variable should be of order I(1), which holds true in our present case. Therefore, the application of the PMG method is justified.

The ARDL (p,q...) can be represented as follows:

$$
y_{i t}=\sum_{j=1}^{p} \lambda_{i j} y_{i, t-j}+\sum_{j=0}^{q} \delta_{i j}^{\prime} x_{i, t-j}+v_{i}+\varepsilon_{i t}
$$

Equation (3) can be re-written as:

$$
\Delta y_{i t}=\varphi_{i} y_{i, t-1}+\beta_{i}^{\prime} x_{i t}+\sum_{j=1}^{p-1} \lambda_{i j}^{*} \Delta y_{i, t-j}+\sum_{j=o}^{q-1} \delta_{i j}^{* \prime} \Delta x_{i, t-j}+v_{i}+\varepsilon_{i t}
$$

In Eq. (3), $y_{i t}, x_{i t}, v_{i}$ represent the dependent variable, explanatory variables, and fixed effects, respectively; $\varepsilon_{i t}$ is the independent and identically distributed (IID) error term, and ' $i$ ' and ' $t$ ' represent the cross-sectional units and time, respectively. The specification (3) can be augmented with a time trend or any other fixed-type regressors, such as seasonal dummies (Pesaran et al. 1999). We augment Eq. (3) with time dummies $\left(\theta_{t}\right)$ to control for the effects of any common time-varying shocks, and the other two dummies.

To examine the second objective, that is, which among the per capita income growth determinant factors crucially affects the interstate income inequality, this study considers similar methodologies but in a time-series context, not in a panel model. It uses the ARDL bounds testing approach to cointegration as propounded by Pesaran et al. (2001). Hence, we report the long-run estimates of our growth model 
that are based on PMG estimator and the estimates of income inequality model based on time-series ARDL procedures.

\section{Discussion}

This section discusses the results in two parts. First, it focuses on examining growthpromoting developmental government expenditure components along with other crucial factors determining the economic growth of state economies. Second, it focuses on examining whether the growth-promoting factors induce income inequality across Indian states.

\subsection{An analysis of economic growth rates across the Indian states}

Table 2 shows that coefficients of property right enforcement, human capital formation, public expenditures on economic services, health and education, and private investment in rural areas have positive and statistically significant relationships with economic growth. To check the robustness of our results, we re-estimate our growth model (1) by adding three additional variables along with altering their lag structures. This is done to capture the structural changes, the effects of the 1997-2000 crisis, and the effects of the 2008-2010 financial crisis. ${ }^{15}$ Levine and Renelt (1992) argued that "...the relationship between growth and a particular variable [is] of interest to be robust if it remains statistically significant and of the theoretically predicted sign when the conditioning set of variables in the regression changes." We have incorporated the ratio of non-agricultural output to agricultural output to capture structural changes in Indian states and also control for any external shocks on account of trade and investment. ${ }^{16}$ Table 2 confirms that our results remain consistent after controlling for the effects of the above-mentioned variables and even after changing the lag structure.

Appendix Table 7 substantiates the positive relationship between property rights enforcement and economic growth by showing that there was a significant improvement in the former for a majority of Indian states, including poorer states like Bihar, Uttar Pradesh, Orissa, Tamil Nadu, and Karnataka, between 1991 and 2017, which may explain its positive contribution on economic growth. This is found to

\footnotetext{
15 The period 1997-2000 was extraordinary for India. Challenges existed not only on the external economic front due to the East Asian Financial crisis, but also on the political and international relations fronts. There was political instability at the Centre, along with the Kargil War with Pakistan and economic sanctions after the 1998 nuclear test (Wadhava, 1998). Therefore, it is imperative to control for these incidents in our growth model.

16 In order to represent India's structural problems determining the economic conditions or living standards of the people, we tried to incorporate the unemployment rate across Indian states. However, the Reserve Bank of India (RBI), including the NSSO, provides data only for specific years: 1993, 1999, 2004, 2011, and 2017. No official source provides continuous time series information on state-wise unemployment rates. Therefore, such analysis was not possible, even with interpolation, and the variable was subsequently dropped.
} 


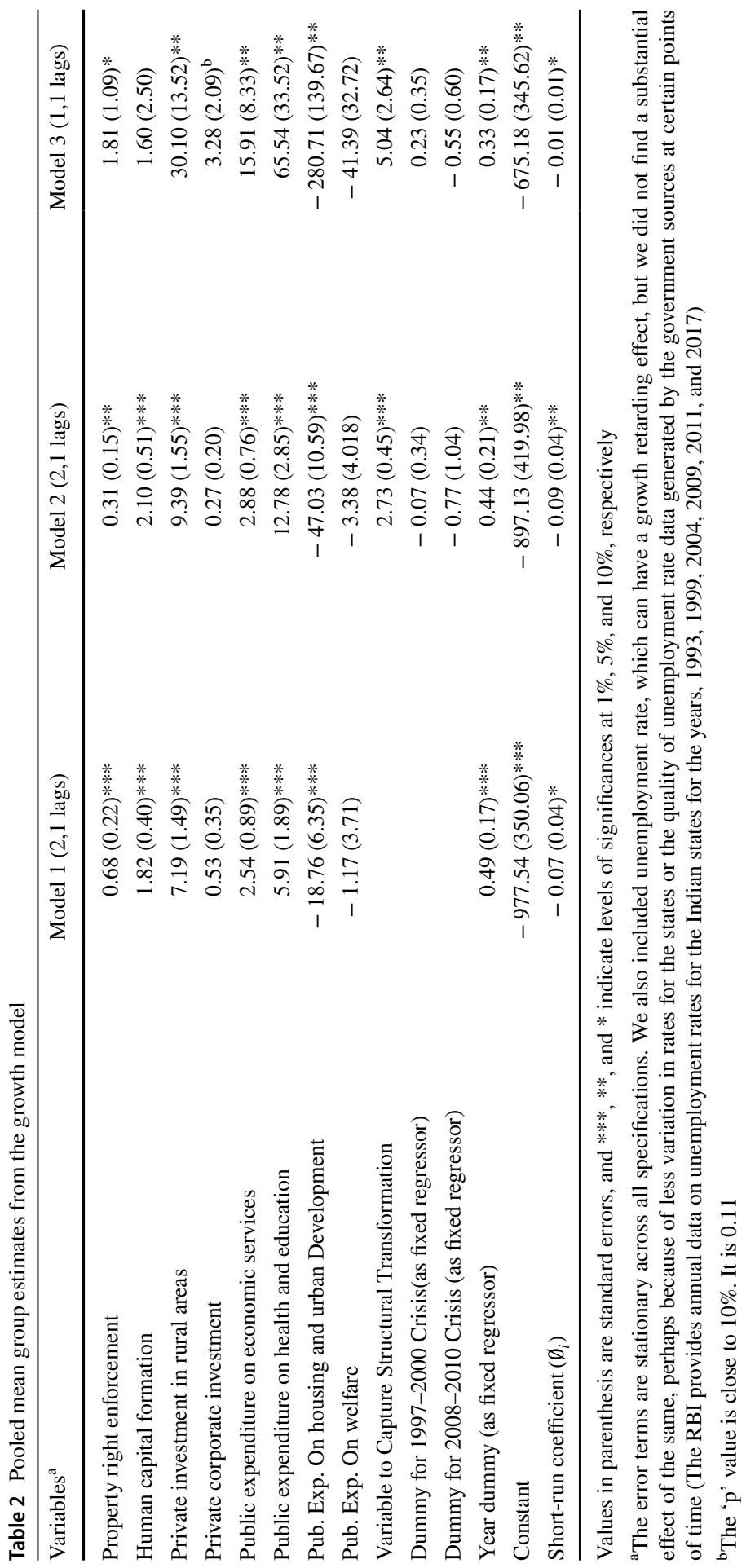


be consistent with the prediction of the institutional theory of growth, which points out that the enforcement of property rights fosters economic growth through various channels by incentivizing all economic agents to engage in productive economic activities, irrespective of whether they belong to the formal or informal sector. Secured property rights also facilitate transactions between economic agents. Market-based economies flourish on transactions. An individual with secured property can use it as collateral to obtain loans from formal banking institutions for productive purposes. Researchers have also observed that one of the factors responsible for the surge in Bihar's economic growth is the reduction in crime rates. ${ }^{17}$ Thus, secure property rights and an efficient law and order situation in a state can help its growth, incentivize people to make productive investments, facilitate transactions, and check rent-seeking behavior. Multilateral institutions such as the International Monetary Fund (IMF) have been urging countries to strengthen their economic institutions to increase their resilience in the face of unprecedented challenges, such as the recent COVID-19 pandemic. $^{18}$

Public developmental expenditures on economic services and health and education maintain positive relationships with per capita income, implying they complement or act as inputs in the productive activities of private economic agents. Public services such as health care and education in low-level income regions help achieve more equitable economic growth. One out of five persons in India spends their life in poverty (World Bank, 2016) ${ }^{19}$; hence, the provision of health and education services cannot be left to the private sector alone. Insufficient investment by governments (at the federal as well as sub-federal levels) in the health sector can push a significant number of Indian households into a vicious poverty trap (Berman et al. 2010). The recent COVID-19 crisis has also highlighted the importance and need for a robust public health system wide across the countries. The Indian government allocates less than $1 \%$ of GDP on health, much less compared with the other BRICS nations (Brazil, Russia, China, and South Africa). ${ }^{20}$ When the COVID-19 pandemic struck India, the government was forced to impose a severe or complete lockdown to prepare its shaky healthcare system to deal with the imminent health crisis. $^{21}$ The lockdowns imposed in India, although believed to be improperly planned without envisioning the effects on internal migration and the livelihoods of vulnerable sections of society, gave ample time to the federal and sub-federal governments to prepare for the enormous challenges. It is seen that even the federal government stretched the lockdown period than originally planned but even then because of larger failures by different governments to control the spread and shortage of medical facilities and equipment, most of the states and local governments in different regions further extended the lockdown period bringing miseries in the life of poor

\footnotetext{
17 https://www.ideasforindia.in/topics/trade/political-change-and-crime-reduction-in-bihar.html

18 Strengthening Economic Institutions for a resilient recovery ( Source: International Monetary Fund's Blog).

19 India's poverty profile ( Source: The World Bank).

20 Trends in catastrophic health expenditure in India: 1993 to 2014 (Source: World Health Organization).

21 India coronavirus: Why is India reopening amid a spike in cases ( Source: British Broadcasting Corporation).
} 
and middle-income people. Further, it was not like the trade-off between economic well-being and lives as seen in the advanced countries but like lives versus lives in the absence of proper medical facilities (Lancet 2020; Ray et al. 2020).

Public economic services expenditures in India include major seven components: (1) agriculture and allied activities, (2) rural development, (3) irrigation and flood control, (4) energy, (5) industry and minerals,(6) transport and communication, (7) science, technology and environment. By acting as complementary physical inputs into the production function of private producers, public economic services contribute to enhancing productivity and economic growth. Micro-, medium-, and small-scale enterprises are the pillars of the Indian economy, contributing to a significant proportion of India's total GDP and employing a large section of the population. ${ }^{22}$ Climate change due to global warming is associated with many phenomena like sudden heavy downpours, severe drought, coastal erosion, groundwater depletion, extreme heatwaves, etc. These affect agricultural productivity and other economic activities. India is one of the countries most vulnerable to climate change. Sudden downpours in India cause heavy floods, landslides and heavy soil erosion. ${ }^{23}$ So, the government must focus on building public infrastructure to cope with such unforeseeable events.

The coefficient on human capital, which is captured by the size of the population enrolled in higher education, also has a positive association with economic growth. This is in line with endogenous growth theory, which establishes that human capital is likely to exert a positive spillover effect as it not only improves the productivity of individuals who receive knowledge, but also those in the periphery who reap gains, contributing to overall economic productivity and growth.

Of the two variables used to capture private investments, our study finds a positive effect of private sector investment in rural areas on the states' economic growth. This implies that credit disbursements by banks in rural areas lead to higher economic growth in states. This reinforces the findings of Burgess and Pande (2005) and Mohan (2006), who observed that state-sponsored banking expansion in rural areas helped rural households accumulate more capital and obtain loans for long-term productive investments, thus helping raise farm productivity in India. Meller and Lele (1973) and Meller (1976) also established that the growth of the farm sector helped that of the non-farm sector as well. The growth of the farm sector generates incomes for farmers as well as demand for goods in other sectors, such as industries supplying farm inputs and consumer goods. Lanjouw \& Shariff (2004) noted that there existed a direct relationship between the growth of agricultural wages and the growth of the non-farm sector. This means that credit disbursed by banks in rural areas creates a virtuous cycle, helping not only the growth of the farm sector but also the non-farm sector. However, although the sign of the coefficient on private corporate investment

\footnotetext{
$\overline{22}$ Robust public economic infrastructure such as energy will help them significantly. In India, largescale industries rely on in-house captive power facilities to meet their energy demand (various issues of All India Electricity Statistics). Micro, medium \& small industry ( Source: Confederation of Indian Industry).

23 More floods, severe heat wave: Government predicts climate change impact on India this century (Source: The Print). India: Impact of Climate Change to 2030 A Commissioned Research Report (Source: Office of Director of National Intelligence).
} 
is found to be positive, it is insignificant in our growth model. The coefficient of expenditure on housing and urban development has a negative relationship with per capita income, whereas the coefficient of welfare remains statistically insignificant. Since we do not have any further information on the sub-components constituting urban and housing development expenditure heads of the government, we are unable to offer any concrete explanations for such a relationship. This is because there exist a plethora of urban projects for sheltering the urban poor. It is difficult to infer why it has a negative relationship with the states' growth. Further information is required regarding the domains of urban areas wherein governments are allocating relatively more expenditure and the timeliness of completion of urban development projects. This needs separate treatment for further investigation and can be explored in future research. The expenditures on welfare programs mainly comprise transfer incomes for the welfare enhancement of poor and socially underprivileged sections of Indian society. This is in line with Barro (1990), who argued that welfare expenditure is an end in itself, rather than a means for increasing economic growth. ${ }^{24}$ Welfare programs in developing countries are not properly implemented and face a host of problems like exclusion and inclusion errors, corruption, lack of predictability, etc. To deal with these issues, Muralidharan et al. (2016) advocated the use of biometrically authenticated infrastructure in welfare program implementation.

Structural transformation also has a positive and statistically significant relationship with economic growth. It reflects the transition of states' economies from agricultural to non-agricultural. Dummies capturing both crises are found statistically insignificant in all specifications. The East Asian crisis of 1997 had very little impact on the Indian economy (RBI; Fifth L.K. Jha Memorial Lecture) ${ }^{25}$ To counter the 2008 global crisis, the Indian government had deviated from the fiscal consolidation path (FRBM Review Committee Report(GOI); Volume 1). ${ }^{26}$ This may have helped to counter its negative effects.

Moreover, our empirical findings suggest that if a state wants to achieve faster and high economic growth, it must focus on strengthening the institutions responsible for ensuring enforcement of property rights along with other supplementary institutions. Indian states are majorly held responsible for the provision of general health, education, and basic public economic services to their citizens. This also includes investment in animal husbandry, irrigation, power, transport, communication, etc. Parallelly, state governments must also exhibit efficiency in providing welfare services by minimizing inclusion and exclusion errors and improve the efficiency of housing and urban development expenditures.

\subsection{An analysis of income inequality across Indian states}

Property rights enforcement, human capital formation, public expenditure on health and education, public expenditure on economic services and private investment in

\footnotetext{
24 Drèze and Khera (2017) have found that welfare programs in India promote human well-being.

25 Fifth LK Jha Lecture (Source: Reserve Bank of India).

${ }^{26}$ FRBM Review Committee Report, Vol(1) (Source: Department of Economic Affairs, Government of India).
} 
rural areas have demonstrable positive and robust relationships with states' per capita incomes. However, this raises another interesting question as to whether the same variables also explain income inequality among the Indian states. This hypothesis derives its legitimacy from the famous Kuznets curve, which illustrates that per capita income and income inequality have an inverted-U-shaped relationship. Hence, if a factor under investigation affects per capita income, we examine whether the same factor also affects income inequality.

To examine this hypothesis, we compute Gini coefficients for our variables of interest: (1) per capita income, (2) property rights enforcement, (3) human capital formation, (4) public expenditure on health and education, (5) public expenditure on economic services, and (6) private investment in rural areas. The Gini coefficients for variables (1)-(3) are directly computed as they are comparable across states.

Then, at first, we attempt to make public expenditure on health and education, private investment in rural areas, and public expenditure on economic services comparable across states. In order to do so, we convert total public allocations on economic services, and health and education services into real terms by deflating with respect to the GSDP implicit price deflator and then we divide those resultant series by the respective state's population (in thousands). This yields a comparable data set for computing the Gini coefficients of the corresponding indicators. A similar approach has also been adopted for private investment in rural areas. ${ }^{27}$

Finally, we construct a time-series model where the interstate income inequality is expressed as a dependent variable, and all others are treated as explanatory variables for the period 1991-2017. Equation (5) depicts the functional relationship among the variables.

Income Inequality ${ }_{i}=\alpha+$

$\beta_{1}$ Interstate Disparity in Enforcement of Property Right $t_{t}+$

$\beta_{2}$ Inter State Disparity in Public Economic Services +

$\beta_{3}$ Interstate Disparity in Health \& Education Services ${ }_{t}+$

$\beta_{4}$ Inter State Disparity in Private Investment in Rural Areas ${ }_{t}+$ $\beta_{5}$ Inter State Disparity in Human Capital $_{t}+\varepsilon_{t}$

Furthermore, to check the robustness of our results, we re-estimate our inequality model with Gini values of the structural transformation variables that have been used in our growth model to capture the interstate disparities in the GSDP compositions of states. ${ }^{28}$

\footnotetext{
${ }^{27}$ In this case, the rural populations of states are used instead of the total population for an appropriate comparison.

${ }^{28}$ A limitation associated with the Gini coefficient is that it is not easily decomposable- the total Gini for an economy is not equal to the sum of the Gini coefficients of its subgroups (Haughton and Khandker 2009). However, our aim is to obtain the level of inequality among the Indian states. Several empirical works, involving cross-country studies, have also used Gini measure to estimate income inequality (Alesina and Rodrik, 1994; Chong and Gradstein 2007; Rosser et al. 2000; Voitchovsky 2005).
} 
Prior to estimating the parameters in the income inequality equation using timeseries procedures, we first investigate the unit root property of the constructed series incorporated in the model. The ADF test is used to check the stationarity of the variables. Table 9 of Appendix shows the presence of mixed orders $\{I(1)$ and $I(0)\}$ of variables. Pesaran and Shin (1998) suggested the use of an ARDL modeling approach as an appropriate estimation strategy in presence of $I(1)$ and $I(01)$ variables or in the context of uncertainties shrouding the testing of the time-series properties of variables. This estimation strategy, popularly known as the bounds testing approach to cointegration, provides two sets of critical values (upper and lower) and yields consistent estimates both in the short run and long run. The upper and lower values provided assume that all the variables entered in the model are $I(1)$ and $I(0)$, respectively. If the computed F-statistic lies above the critical F-value corresponding to $I(1)$ or the upper limit, we infer that a cointegration relationship exists among the variables. Otherwise, cointegration cannot be confirmed. The results on the bounds test are estimated for two models corresponding to our inequality equation by changing the lag structure of variables to assess the consistency of the original model estimates as shown in Eq. (5). The results reported in Appendix Table 10 show that with both the lags, there exist long-run relationships among variables in the inequality model. Then, we estimate the long-run parameters of the model. Moreover, we reestimate Eq. (5) by augmenting the Gini coefficient for structural inequality among Indian states, the results of which are reported in Appendix Tables 11, 12. A robust relationship is confirmed between the interstate differences in per capita income levels and the provisioning of public economic services.

Table 3 shows that the divergence in levels of income across states is driven by differences in the provisioning of public economic services, controlling for other factors. Economic services include the allocation of funds on the development of energy, industry, rural development, agriculture and allied activities, transport and communication, science and technology, etc. ${ }^{29}$ These factors serve as inputs in production. Therefore, it is equally likely that a state with deficient public infrastructure has a lower concentration of non-farm economic activities or even a less-developed primary sector. Well-developed public infrastructure in agriculture (cold storage, storage and irrigation facilities, etc.) help farmers to add value or fetch better prices for their crops. The average landholding size in India is decreasing continuously, thereby affecting farmers' capacity to invest in productive inputs. Therefore, public agricultural infrastructure is necessary for farmers to be more resilient in facing uncertainties arising from climate change. It may not be possible to imagine the internet of things (IoT) in the absence of well-developed energy and communication sectors. IoT is likely to be one of the main drivers of economic growth in the coming years (World Investment Report, 2019).

\footnotetext{
29 Rao et al. (1999) and Ahluwalia (2000) observed that the key driving force behind wider interstate income inequalities in India is the interstate disparity in private investment. Mallick (2014) finds that there is convergence of income among the Indian states conditional upon private investment and public investment. He captures the public investment by combining the revenue and capital expenditures of the central and state governments.
} 
On the other hand, the results on all other variables show an inconsistent relationship with interstate income inequality. Therefore, it becomes cumbersome to provide any possible explanations for such inconsistent results. One needs to conduct further research in examining the other factors affecting interstate income inequality. One perhaps needs to answer the questions such as 'how do differences in the economic and political institutions among the states lead to income inequality among them?' and 'how do interstate differences in human capital formation among states lead to interstate income inequality between them?'.

The growth-contributing factors (property rights enforcement, expenditure on health and education and economic services, human capital formation, and private investment) from our preceding results consistently single out the interstate differentials in public economic services allocations as the key driver of income inequality among the Indian states. Therefore, we may infer that the richer states capable of making greater allocations for the provision of economic services (including infrastructural spending) are likely to attract more private investment or incentivize private agents to participate in economic activities more productively compared with less capable states, and this, in turn, contributes to widening the income inequality among the Indian states.

\section{Conclusions and policy recommendations}

This empirical panel data analysis of 16 Indian states over the period 1991-2017 firmly concludes that the quality of economic institutions (measured using property rights) and the government expenditure on health and education and economic services play positive and statistically significant role in influencing the economic growth of Indian states. Among the growth-contributing factors, it is the interstate differences in public economic services that contribute to interstate differences in the levels of per capita income across states.

In light of the findings that the enforcement of property rights matters for promoting growth, this study suggests that state governments should strengthen their public administrative (governance) institutions and ensure the protection of private property rights. Besides maintaining proper law and order under their jurisdictions, state governments in collaboration with the Government of India (GOI) and the Supreme Court of India (SCI) should also address the problems of the judiciary and ensure that the modern justice system is accessible, timely, and affordable for every citizen (including residents). This will strengthen the faith of the people including economic agents outside the Indian economy in the formal institutions of the country. The recent enactment of the Insolvency and Bankruptcy (IBC) code in 2016 to deal with cases regarding insolvency and the organization of corporate houses is a step in the right direction. However, this enactment is held up by pending cases (Press Information Bureau of India, $3^{\text {rd }}$ December 2019). ${ }^{30}$ Many offences of an economic

\footnotetext{
30 https://pib.gov.in/PressReleaseIframePage.aspx?PRID=1594698 \& https://www.bloombergquint.com/ law-and-policy/10-860-cases-under-ibc-pending-before-nclt-at-the-end-of-sep-govt.
} 
Table 3 ARDL estimates on income inequality

\begin{tabular}{lll}
\hline Variables $^{\mathrm{a}}$ & Model (1) & Model (2) \\
\hline Interstate inequality in provision of public economic services & $0.44(0.013)^{* *}$ & $0.39(0.001)^{* * *}$ \\
Interstate inequality in property right enforcement & $-0.18(0.058)^{*}$ & $-0.09(0.21)$ \\
Interstate inequality in public health and education services & $-0.05(0.85)$ & $-.28(0.04)^{* *}$ \\
Interstate inequality in private investment in rural areas & $0.007(0.75)$ & $0.01(0.61)$ \\
Interstate inequality in human capital formation & $-0.056(0.42)$ & $-0.08(0.07)^{*}$ \\
Error-correction term (- 1) & $-.88(.001)^{* * *}$ & $-.82(.000)^{* * *}$ \\
\hline
\end{tabular}

Values in parenthesis are standard errors, and ***,**, and * indicate levels of significances at $1 \%, 5 \%$, and $10 \%$, respectively

${ }^{\text {a }}$ The results reported in Table 2 of the growth model and Table 11 of Appendix satisfy the conditions of normality and no-serial correlation property of the error term

and criminal nature either remain under-investigated or under trial. The current president of India (Shri Ram Nath Kovind) once rightly observed that the "Indian legal system is marked by long delays, the huge backlog of cases in courts as indicated from 3.3 crores of the backlog of cases in different Indian courts". ${ }^{31}$ Therefore, a focus on bringing efficiency to the justice delivery system should be on the priority list of future policy reforms.

Based on the findings that expenditure on health and education and economic services are the crucial sub-components of development expenditures along with human capital in contributing to the economic growth of the Indian states, this study suggests that policy planners should focus more on these sub-heads of developmental expenditures, make the delivery of welfare schemes for the poor and underprivileged sections more efficient, and ensure the timely completion of housing and urban development projects. Along with the GOI, the state governments should ensure that the country's higher education system is accessible and affordable to all, not only focusing on increasing enrollment but also ensuring that the education system inculcates skills and values in all the youths in line with the demands of an era with massive deployment of disruptive technologies involving the use of artificial intelligence (AI). A robust modern public health and education system with resilient public infrastructure and developed economic institutions will go a long way toward putting the Indian economy on a sustainable growth path and increasing its crisis management capabilities.

This study also finds that within development expenditures, it is the regional disparities in the provision of public economic services that contribute to income differences across states. Therefore, it is the responsibility of the GOI to help economically weaker states in providing the basic economic services. This can be addressed with the help of the Finance Commission(FC), a constitutional body for resource sharing between the center and states, as well as interstate and intra-sate resources

\footnotetext{
31 https://economictimes.indiatimes.com/news/politics-and-nation/indian-legal-system-is-marked-bylong-delays-huge-backlog-of-cases-in-courts-president-kovind/videoshow/65634599.cms.
} 
allocations done by various local bodies for addressing the regional economic differences. The FCs devise the principles to govern tax revenue sharing (from the divisible pool) between both tiers of governments (federal and sub-federal) and provides specific and general purpose grants from its non-tax revenue sources for improving the performance of specific sectors at the local levels. Since the inception of FCs, their recommendations have helped the governments in improving the quality of public spending and fiscal stability in India. ${ }^{32}$

Additionally, the policy planners of India must focus on bridging the income gaps among the people in different regions. The economically less well-off Indian states are also among the most populous. The skewed availability of public economic services further aggravates the income disparities across states and requires dedicated policy focus and planning, lest it becomes a recipe for future regional conflicts and less cooperation among them as witnessed in the history.

\section{Data availability statement}

We have the data relating to the study that can be provided upon a request to the corresponding author at any point of time.

\section{Appendix}

See Tables 4, 5, 6, 7, 8, 9, 10, 11, and 12 .

Table 4 Asymptotic difference of balanced panel unit root tests

\begin{tabular}{llll}
\hline Test & Options & Asymptotic & Panel \\
\hline LLC & Without constant & $\sqrt{N} / T \rightarrow 0$ & \\
& Constant & $N / T \rightarrow 0$ & Balance \\
& Trend & $N / T \rightarrow 0$ & Balance \\
& Without constant & $N \rightarrow \infty, \mathrm{T}$ fixed & \\
HT & Constant & $N \rightarrow \infty, \mathrm{T}$ fixed & Balance \\
& Trend & $N \rightarrow \infty, \mathrm{T}$ fixed & Balance \\
HT & Without constant & $(N, T) \rightarrow \infty$ & Balance \\
BT & Constant & $(N, T) \rightarrow \infty$ & \\
& & $(N, T) \rightarrow \infty$ & \\
BT & & & \\
\hline
\end{tabular}

32 https://fincomindia.nic.in/. 
Table 5 Cross-sectional dependence test results

\begin{tabular}{|c|c|c|c|c|}
\hline Variables & $\begin{array}{l}\text { Breusch- } \\
\text { Pagan (LM) }\end{array}$ & $\begin{array}{l}\text { Pesaran } \\
\text { scaled(LM) }\end{array}$ & $\begin{array}{l}\text { Bias- } \\
\text { corrected } \\
\text { LM }\end{array}$ & Pesaran CD \\
\hline Real per capita income & $0.0 *(3150.39)$ & $0.0(195.61)$ & $0.0(195.30)$ & $0.0(56.12)$ \\
\hline Property rights enforcement & $0.0(237.98)$ & $0.0(7.61)$ & $0.0(7.30)$ & $0.7(-.34)$ \\
\hline Human capital formation & $0.0(2131.04)$ & $0.0(129.81)$ & $0.0(129.50)$ & $0.0(43.34)$ \\
\hline Private investment in rural areas & $0.0(2227.47)$ & $0.0(136.03)$ & $0.0(135.72)$ & $0.0(45.60)$ \\
\hline Private corporate investment & $0.0(676.22)$ & $0.0(35.90)$ & $0.0(35.59)$ & $0.0(22.34)$ \\
\hline Public expenditures on economic services & $0.0(480.92)$ & $0.0(23.29)$ & $0.0(22.98)$ & $0.0(5.37)$ \\
\hline Public expenditures on health and education & $0.0(463.08)$ & $0.0(22.14)$ & $0.0(21.83)$ & $0.0(8.90)$ \\
\hline $\begin{array}{l}\text { Public expenditures on housing and urban } \\
\text { Development }\end{array}$ & $0.0(1021.58)$ & $0.0(58.19)$ & $0.0(57.88)$ & $0.0(26.01)$ \\
\hline Public expenditures on welfare & $0.0(1454.30)$ & $0.0(86.13)$ & $0.0(85.82)$ & $0.0(33.09)$ \\
\hline
\end{tabular}

${ }^{*}$ Signifies the significance level at $1 \%$. The above results are computed using EViews

Table 6 LLC panel unit root test results (after de-meaning each series)

\begin{tabular}{|c|c|c|c|c|}
\hline & \multicolumn{2}{|l|}{$\mathrm{I}(0)$} & \multicolumn{2}{|l|}{$\mathrm{I}(1)$} \\
\hline & Statistics & $P$ value & Statistics & $\mathrm{P}$ value \\
\hline Real per capita income & 7.22 & 1 & -8.29 & $0.0 * * *$ \\
\hline Property rights enforcement & -2.93 & 0.0017 & & \\
\hline Human capital & -2.87 & 0.002 & & \\
\hline Private investment in rural areas & 2.76 & 0.997 & -7.13 & $0.0 * * *$ \\
\hline Private corporate investment & -4.97 & $0.0 * * *$ & & \\
\hline Public expenditures on economic services & -0.56 & 0.28 & -7.5 & $0.0 * * *$ \\
\hline Public expenditures on health and education & -4.92 & $0.0 * * *$ & & \\
\hline Public expenditures on housing and urban development & 0.4956 & 0.6899 & & \\
\hline Public expenditures on welfare & 1.49 & 0.93 & -6.71 & $0.0 * * *$ \\
\hline
\end{tabular}

\footnotetext{
**** Signifies the significance at $1 \%$. The above results are calculated in STATA
} 
Table 7 Property right enforcement index across Indian states

\begin{tabular}{lccc}
\hline Indian States & 1991 & 2017 & $\begin{array}{l}\text { Average } \\
(1991- \\
2017)\end{array}$ \\
\hline Andhra Pradesh & 43.7 & 50.91 & 45.2 \\
Bihar & 14 & 19.61 & 16.23 \\
Goa & 18.4 & 21.23 & 14.45 \\
Gujarat & 22.6 & 25.15 & 17.59 \\
Haryana & 74.4 & 32.95 & 55.2 \\
Karnataka & 35.1 & 38.47 & 35.07 \\
Kerala & 20.9 & 24.22 & 16.28 \\
Madhya Pradesh & 51.2 & 32.53 & 36.98 \\
Maharashtra & 21.2 & 29.53 & 17.66 \\
Odisha & 8.7 & 28.43 & 26.31 \\
Punjab & 52.6 & 46.38 & 51.03 \\
Rajasthan & 69.1 & 53.61 & 57.57 \\
Tamil Nadu & 55.4 & 66.16 & 60.46 \\
Uttar Pradesh & 18.8 & 40.91 & 37.11 \\
West Bengal & 31.7 & 15.78 & 24.23 \\
Delhi & 16.3 & 11.15 & 8.06 \\
Averages & 34.63 & 33.56 & 32.46 \\
\hline
\end{tabular}

Source: NCRB 
Table 8 Average values of some variables

\begin{tabular}{|c|c|c|c|c|}
\hline State & $\begin{array}{l}\text { Average Agri- } \\
\text { cultural Credit } \\
\text { (1991 to 2017) }\end{array}$ & $\begin{array}{l}\text { Av. Property } \\
\text { Rights Enforce- } \\
\text { ment (1991- } \\
\text { 2017) }\end{array}$ & $\begin{array}{l}\text { Av. Human } \\
\text { Capital Forma- } \\
\text { tion (1991- } \\
2017)\end{array}$ & $\begin{array}{l}\text { Av. share of Agriculture and Allied } \\
\text { to Non-Agriculture (1991-2017) }\end{array}$ \\
\hline $\begin{array}{l}\text { Andhra } \\
\text { Pradesh }\end{array}$ & 8.87 & 45.2 & 7.57 & 0.351005 \\
\hline Bihar & 4.48 & 16.23 & 5.07 & 0.343412 \\
\hline Goa & 1.01 & 14.45 & 8.65 & 0.095782 \\
\hline Gujarat & 3.11 & 17.6 & 6.8 & 0.173854 \\
\hline Haryana & 5.7 & 55.2 & 7.05 & 0.432553 \\
\hline Karnataka & 6.17 & 35.07 & 8.08 & 0.268524 \\
\hline Kerala & 5.34 & 16.28 & 6.2 & 0.259081 \\
\hline $\begin{array}{l}\text { Madhya } \\
\text { Pradesh }\end{array}$ & 5.37 & 36.98 & 5.16 & 0.449275 \\
\hline $\begin{array}{l}\text { Maharash- } \\
\text { tra }\end{array}$ & 2.56 & 17.66 & 8.12 & 0.183303 \\
\hline Odisha & 4.4 & 26.31 & 4.8 & 0.344568 \\
\hline Punjab & 7.65 & 51.03 & 6 & 0.557251 \\
\hline Rajasthan & 5.89 & 57.57 & 4.74 & 0.426487 \\
\hline $\begin{array}{l}\text { Tamil } \\
\text { Nadu }\end{array}$ & 5.39 & 60.46 & 8.01 & 0.156811 \\
\hline $\begin{array}{l}\text { Uttar } \\
\text { Pradesh }\end{array}$ & 5.94 & 37.11 & 6.67 & 0.376363 \\
\hline $\begin{array}{l}\text { West } \\
\text { Bengal }\end{array}$ & 2.24 & 24.21 & 5.21 & 0.402782 \\
\hline Delhi & 3.42 & 8.06 & 10.09 & 0.013728 \\
\hline
\end{tabular}

Data Sources: NCRB, RBI, EPWRF, AISHE 
Table 9 Augmented Dickey-Fuller (ADF) unit root test results

\begin{tabular}{lll}
\hline Variables & $\mathrm{I}(0)$ & $\mathrm{I}(1)$ \\
\hline Interstate income inequality & 0.22 & $0.0013 * * *$ \\
Interstate inequality of public economic services & $0.03 * *$ & \\
Interstate inequality of public health and education services & 0.26 & $0.04 * *$ \\
Interstate inequality of private investment in rural areas & 0.98 & $0.0007 * * *$ \\
Interstate inequality of property rights enforcement & 0.78 & $0.009 * * *$ \\
Interstate inequality of human capital & 0.62 & $0.0009 * * *$ \\
\hline
\end{tabular}

***,$* *$, and $*$ Signify the significance at $1 \%, 5 \%$, and $10 \%$

Table 10 Bounds test results

\begin{tabular}{lllll}
\hline Model 1 & $(1,1$ lags $)$ & Model 2 & $(2,0$ lags $)$ \\
\cline { 2 - 3 } Significance & $\mathrm{I}(0)$ & $\mathrm{I}(1)$ & $\mathrm{I}(0)$ & $\mathrm{I}(1)$ \\
\hline $10 \%$ & 2.26 & 3.35 & 2.26 & 3.35 \\
$5 \%$ & 2.62 & 3.79 & 2.26 & 3.79 \\
$1 \%$ & 3.41 & 4.68 & 3.41 & 4.68 \\
F-statistics value: 3.44 & & & F-statistics: 6.45 \\
\hline
\end{tabular}

Table 11 Re-estimated results for income inequality model

\begin{tabular}{lll}
\hline Variables & Model (1) & Model (2) \\
\hline Interstate inequality in provision of public economic services & $0.61(0.11)^{* * *}$ & $0.62(0.13)^{* * *}$ \\
Interstate inequality in property right enforcement & $-0.14(0.09)$ & $-0.11(0.14)$ \\
Interstate inequality in public health and education services & $0.30(0.18)$ & $0.06(0.31)$ \\
Interstate inequality in private investment in rural areas & $-0.02(0.03)$ & $-0.03(0.04)$ \\
Interstate inequality in human capital formation & $-0.09(0.06)$ & $-0.09(0.08)$ \\
Interstate structural inequality & $0.08(0.07)$ & $0.17(0.11)$ \\
Error-correction term (- 1) & $-0.89(0.16)^{* * *}$ & $-0.71(0.11)^{* * *}$ \\
\hline
\end{tabular}

*** Signifies the significance at $1 \%$. Model (1) and model (2) show the results if we change the lag structure. We have performed this to validate our results

Table 12 Bounds test results for Table 11

\begin{tabular}{lllll}
\hline Model 1 & $(1,1$ lags $)$ & Mode 2 & $(2,0$ lags $)$ \\
\cline { 2 - 3 } Significance & $\mathrm{I}(0)$ & $\mathrm{I}(1)$ & $\mathrm{I}(0)$ & $\mathrm{I}(1)$ \\
\hline $10 \%$ & 1.75 & 2.87 & 1.75 & 2.87 \\
$5 \%$ & 2.04 & 3.24 & 2.04 & 3.24 \\
$1 \%$ & 2.66 & 4.05 & 2.66 & 4.05 \\
F-statistics value: 2.97 & & & F-statistics: 3.49 \\
\hline
\end{tabular}


Acknowledgements We are extremely thankful to two anonymous reviewers of the journal for providing us their constructive suggestions and thoughtful insights. We also acknowledge Ms. Amrita Brahmo for going through our complete manuscript and suggesting us some valuable changes to enhance the quality of the analysis in it. We also acknowledge the National Institute of Public Finance and Policy (NIPFP) for providing us the access to the CapEx database for carrying out our empirical analysis.

Funding This study is not funded by any organization.

\section{Declaration}

Conflict of interest Thus, we hereby declare that there is no conflict of interest with any whatsoever.

\section{References}

Acemoglu D, Johnson S, Robinson JA (2001) The colonial origins of comparative development: an empirical investigation. Am Econ Rev 91(5):1369-1401

Acemoglu D, Johnson S, Robinson JA (2005) Institutions as a fundamental cause of long-run growth. Handbook Econ Growth 1:385-472

Aghion P, Burgess R, Redding SJ, Zilibotti F (2008) The unequal effects of liberalization: evidence from dismantling the License Raj in India. Am Econ Rev 98(4):1397-1412

Ahluwalia M (2000) State-level performance under economic reforms in India. Stanford King Center on Global Development Working Paper No. 96

Aiyar S, Mody A (2011) The Demographic dividend: evidence from the Indian states. International Monetary Fund. Working Paper No. 11(38)

Alesina A, Rodrik D (1994) Distributive politics and economic growth. Q J Econ 109(2):465-490

Alvarez J, Arellano M (2003) The time series and cross-section asymptotics of dynamic panel data estimators. Econometrica 71(4):1121-1159

Amin M, Matto A (2008) Human capital and the changing structure of the Indian economy. Policy Research working paper 4576. The World Bank, Washington DC

Baltagi BH (2005) Econometric analysis of panel data. Wiley, London

Banerjee AV (2001) Contracting constraints, credit markets, and economic development. Massachusetts Institute of Technology Department of Economics Working Paper 02-17

Banerjee A, Iyer L (2005) History, institutions, and economic performance: the legacy of colonial land tenure systems in India. Am Econ Rev 95(4):1190-1213

Banerjee AV, Gertler PJ, Ghatak M (2002) Empowerment and efficiency: tenancy reform in West Bengal. J Polit Econ 110(2):239-280

Barro RJ (1990) Government spending in a simple model of endogenous growth. J Political Econ 98(5(Part 2)):S103-S125

Barro RJ (1991) Economic growth in a cross-section of countries. Quart J Econ 106(2):407-443

Benhabib J, Spiegel MM (1994) The role of human capital in economic development evidence from aggregate cross-country data. J Monet Econ 34(2):143-173

Berman P, Ahuja R, Bhandari L (2010) The impoverishing effect of healthcare payments in India: new methodology and findings. Econ Pol Wkly 45(16):65-71

Besley T, Burgess R (2004) Can labor regulation hinder economic performance? Evidence from India. Quart J Econ 119(1):91-134

Besley T, Ghatak M (2010) Property rights and economic development. Handb Dev Econ 5:4525-4595

Breitung J, Das S (2005) Panel unit root tests under cross-sectional dependence. Stat Neerl 59(4):414-433

Breusch TS, Pagan AR (1980) The Lagrange multiplier test and its applications to model specification in econometrics. Rev Econ Stud 47(1):239-253

Burgess R, Pande R (2005) Do rural banks matter? Evidence from the Indian social banking experiment. Am Econ Rev 95(3):780-795

Cashin P, Sahay R (1996) Internal migration, center-state grants, and economic growth in the states of India. Staff Papers 43(1):123-171

Chancel L, Piketty T (2019) Indian income inequality, 1922-2014: From British Raj to Billionaire Raj? Rev Income Wealth 65:S33-S62 
Chong A, Gradstein M (2007) Inequality and institutions. Rev Econ Stat 89(3):454-465

De Hoyos RE, Sarafidis V (2006) Testing for cross-sectional dependence in panel-data models. Stata J 6(4):482-496

Devarajan S, Swaroop V, Zou HF (1996) The composition of public expenditure and economic growth. J Monet Econ 37(2):313-344

Drèze J, Khera R (2017) Recent social security initiatives in India. World Dev 98:555-572

Easterly W, Rebelo S (1993) Fiscal policy and economic growth: an empirical investigation. National Bureau of Economic Research Working Paper No. 4499

Ghosh S, Gregoriou A (2008) The composition of government spending and growth: is current or capital spending better? Oxf Econ Pap 60(3):484-516

Gupta S, Clements B, Baldacci E, Mulas-Granados C (2005) Fiscal policy, expenditure composition, and growth in low-income countries. J Int Money Financ 24(3):441-463

Hai-Anh D, Lanjouw P (2018) Inequality in India on the rise. United Nations University, UNU-Wider Policy Brief

Haughton J, Khandker SR (2009) Handbook on poverty+ inequality. World Bank Publications

IMF (2016) Regional economic outlook: Asia and Pacific. International Monetary Fund, April 2016, 103-25

Iyer L, Mani A, Mishra P, Topalova P (2012) The power of political voice: women's political representation and crime in India. Am Econ J Appl Econ 4(4):165-193

Kar S, Sakthivel S (2007) Reforms and regional inequality in India. Econ Pol Wkly 42(47):69-77

Kneller R, Bleaney MF, Gemmell N (1999) Fiscal policy and growth: evidence from OECD countries. J Public Econ 74(2):171-190

Kumar U, Subramanian A (2012) Growth in India's States in the First Decade of the 21st Century: Four Facts. Econ Pol Wkly 47(3):48-57

Lancet T (2020) India under COVID-19 lockdown. Lancet 395(10233):1315

Lanjouw P, Shariff A (2004) Rural non-farm employment in India: access, incomes and poverty impact. Econ Pol Wkly 39(40):4429-4446

Levin A, Lin CF, Chu CSJ (2002) Unit root tests in panel data: asymptotic and finite-sample properties. J Econom 108(1):1-24

Levine R, Renelt D (1992) A sensitivity analysis of cross-country growth regressions. Am Econ Rev 82(4):942-963

Loayza N, Ranciere R (2005) Financial development, financial fragility, and growth. The International Monetary Fund Working Paper (5) 170

Mallick J (2014) Regional convergence of economic growth during post-reform period in India. Singapore Econ Rev 59(02):1450012

Meller J (1976) Agriculture on the road of industrialization. John Hopkins University Press, Baltimore

Mellor JW, Lele UJ (1972) Growth linkages of the new food grain technologies. Indian J Agric Econ 28(1):1-22

Mohan R (2006) Agricultural credit in India: status, issues and future agenda. Econ Pol Wkly 41(11):1013-1023

Mounk Y (2018) The people vs. democracy: why our freedom is in danger and how to save it. Harvard University Press.

Muralidharan K, Niehaus P, Sukhtankar S (2016) Building state capacity: evidence from biometric smartcards in India. Am Econ Rev 106(10):2895-2929

Nagaraj R, Varoudakis A, Véganzonès MA (2000) Long-run growth trends and convergence across Indian States. J Int Dev 12(1):45-70

Nandan A, Mallick H (2020) Does gender equality matter for regional growth and income inequality? An empirical analysis for the Indian States. J Int Dev 32(4):439-469

Nayyar G (2008) Economic growth and regional inequality in India. Econ Pol Wkly 43(6):58-67

North DC (1986) The new institutional economics. J Inst Theoret Econ 142(1):230-237

North DC (1991) Institutions. J Econ Perspect 5(1):97-112

Pesaran MH (2004) General diagnostic tests for cross-section dependence in panels. The University of Cambridge. Faculty of Economics. Cambridge Working Papers in Economics No. 0435

Pesaran MH (2007) A simple panel unit root test in the presence of cross-section dependence. J Appl Economet 22(2):265-312

Pesaran MH, Shin Y (1998) An autoregressive distributed-lag modelling approach to cointegration analysis. Econometric Society Monograph 31:371-413 
Pesaran MH, Shin Y, Smith RP (1999) Pooled mean group estimation of dynamic heterogeneous panels. J Am Stat Assoc 94(446):621-634

Pesaran MH, Shin Y, Smith RJ (2001) Bound testing approaches to the analysis of level relationships. J Appl Economet 16(3):289-326

Pesaran MH, Ullah A, Yamagata T (2008) A bias-adjusted LM test of error cross-section independence. Econ J 11(1):105-127

Phillips PC, Moon HR (1999) Linear regressions limit theory for nonstationary panel data. Econometrica 67(5):1057-1111

Rao MG, Shand RT, Kalirajan KP (1999) Convergence of incomes across Indian states: a divergent view. Econ Pol Wkly 34(13):769-778

Ray D, Subramanian S, Vandewalle L ( 2020) India's Lockdown, Centre for Economic Policy Research (CEPR) Policy Insight No. 102

Rodrik D, Subramanian A, Trebbi F (2004) Institutions rule: the primacy of institutions over geography and integration in economic development. J Econ Growth 9(2):131-165

Romer PM (1986) Increasing returns and long-run growth. J Polit Econ 94(5):1002-1037

Romer PM (1994) The origins of endogenous growth. J Econ Perspect 8(1):3-22

Rosser JB Jr, Rosser MV, Ahmed E (2000) Income inequality and the informal economy in transition economies. J Comp Econ 28(1):156-171

Sachs JD, Bajpai N, Ramiah A (2002) Understanding regional economic growth in India. Asian Econ Pap 1(3):32-62

Solow RM (1956) A contribution to the theory of economic growth. Quart J Econ 70(1):65-94

Voitchovsky S (2005) Does the profile of income inequality matter for economic growth?. J Econ Growth 10(3):273-296

UNCTAD (2019) World Investment Report. Published by United Nations Conference on Trade and Development

Publisher's Note Springer Nature remains neutral with regard to jurisdictional claims in published maps and institutional affiliations. 